\title{
Site Specific Nutrient Management (SSNM) Using "Nutrient Expert" for Hybrid Maize (Zea mays L.) Under Zero Tillage in Thungabhadra Project (TBP) Command Area of Karnataka
}

\author{
S.R. Anand", J. Vishwanatha and R.H. Rajkumar
}

AICRP on Management of Salt Affected Soils and Use of Saline Water in Agriculture, Agricultural Research Station, Gangavathi -583 227, University of Agricultural Sciences, Raichur, Karnataka, India

*Corresponding author

\section{A B S T R A C T}

The experiment was carried out during Rabi 2012-13 and 2013-14 at Agricultural Research Station, Gangavathi to study the effect of SSNM practice by using nutrient

Keywords

Economics, Grain yield, Hybrid Maize, Nutrient Expert, SSNM, Zero tillage.

Article Info

Accepted:

27 June 2017 Available Online: 10 August 2017 expert on hybrid maize (GK-5029) under zero tillage in TBP command areas of Karnataka. The pooled data of two years revealed that among main plots there was no significant difference between mulch and without mulch treatments with respect to growth and yield parameters. Among different target yield levels, significantly higher grain and stover yield was recorded with SSNM based on target yield of $10 \mathrm{tha}^{-1}\left(9.40\right.$ and $9.84 \mathrm{t} \mathrm{ha}^{-1}$, respectively) as compared to other target yield treatments and recommended dose of fertilizer which recorded significantly the least grain and stover yield (4.90 and $5.72 \mathrm{t} \mathrm{ha}^{-1}$, respectively). Gross returns, net returns and B: C ratio were also significantly higher with SSNM based on target yield of $10 \mathrm{t} \mathrm{ha}^{-1}$ (Rs.1,41,070, Rs. 1,10,803 and 3.59, respectively) as compared to other target yield levels and recommended dose of fertilizer which recorded significantly the least gross returns, net returns and B:C ratio (Rs. 74,232, Rs. 46,143 and 2.65 , respectively). Irrespective of the tillage methods maize yield was significantly higher with SSNM based on NE for the target yield of $10 \mathrm{t} / \mathrm{ha}$ as compared to state RDF and farmers practice. It could be concluded that, SSNM practice based on "Nutrient expert" can be achieve target yield of hybrid maize up to $9.40 \mathrm{t} \mathrm{ha}^{-1}$ in TBP command area of Karnataka.

\section{Introduction}

Maize (Zea mays L.), a crop of worldwide economic importance, provides approximately $30 \%$ of the food calories to more than 4.5 billion people in 94 developing countries. The demand for maize is expected to double worldwide by 2050. Maize is considered as the third most important food crop among the cereals in India and contributes to nearly $9 \%$ of the national food basket (Dass, 2012). In India, it grown in an area of $8.55 \mathrm{~m}$ ha with an average productivity of $2.5 \mathrm{t} \mathrm{ha}^{-1}$, maize contributes to more than half of the coarse cereal production of the country. The annual maize production in India is about $21.7 \mathrm{~m} \mathrm{t}$ with an annual growth rate of 3 to $4 \%$ (ASG, 2011). Maize yields in India need to be increased significantly to sustain this growth rate to meet India's growing food, feed and industrial needs. Area, production and productivity of maize grew impressively during $\mathrm{XI}^{\text {th }}$ plan at a growth rate of 2.6, 8.2 and $4.9 \%$, as a result 
of commendable response both from the producers and industries. Recently, maize is gaining popularity as a rice-maize cropping system in the state of Andhra Pradesh, replacing the second rice crop in the existing rice-rice or rice-rice-pulse cropping systems due to water scarcity in rice and incidence of diseases in pulses. Similarly, maize is also becoming an important crop in Tamil Nadu and Karnataka due to its higher productivity and profitability, and is grown either as a sole crop in Kharif or in sequence after rice during the Rabi season.

Farmers in the region lack knowledge about managing nutrients within this highly demanding cereal system and are often applying inadequate and imbalanced rates. This has resulted in uncertain system yields and raised doubts on long term sustainability. Further, conservation tillage systems pose greater challenges for farmers due to lack of information on efficient nutrient management strategies under these systems. The average maize yields in southern India are much lower than reported attainable yields and one of the key factors responsible for low yields is inadequate and improper fertilization. Current fertilizer use is quite imbalanced to achieve maximum economic yields for new maize hybrids used by farmers. Moreover, nutrient requirement varies from field to- field due to high variability in soil fertility across farmer fields, and single homogenous and suboptimal official state recommendations may not be very useful in improving maize yields. Also, the current scenario of escalating prices of fertilizers demands solutions for optimized use of nutrients. Thus, there is ample opportunity to improve maize yields through the right use of nutrients.

Nutrient Expert, a new, nutrient decision support system (DSS) based on the principles of site-specific nutrient management (SSNM), offers solutions for providing field-specific fertilizer recommendations to improve the yield and economics of maize growing famers in the region. While generating recommendations, NE considers yield response and targeted agronomic efficiency in addition to quantifying the contribution of nutrients from indigenous sources. It also considers other important factors affecting nutrient management recommendations in a particular location and enables crop advisors to provide farmers with fertilizer guidelines that are suited to their farming conditions. The tool uses a systematic approach of capturing site information that is important for developing a location-specific recommendation (Pampolino et al., 2012). While generating recommendations, NE considers yield response and targeted agronomic efficiency in addition to quantifying the contribution of nutrients from indigenous sources. It also considers other important factors affecting nutrient management recommendations in a particular location and enables crop advisors to provide farmers with fertilizer guidelines that are suited to their farming conditions. Currently, IPNI has developed NE for different geographies of Asia and Africa. The objective of this paper is to evaluate and compare the performance of NE-based fertiliser recommendation with state recommendation. Hence, these experiments were conducted in rice fallows of TBP and Upper Krishna command areas of Karnataka.

\section{Materials and Methods}

The experiment was laid out in split plot design with 10 treatments combinations. There were two main plots $\left(\mathrm{M}_{1}\right.$ - Zero tillage with mulch and $\mathrm{M}_{2^{-}}$Zero tillage without mulch) and five sub plots $\left(\mathrm{F}_{1}-\mathrm{SSNM}\right.$ for the target yield of $7 \mathrm{t} / \mathrm{ha}, \mathrm{F}_{2}-\mathrm{SSNM}$ for the target yield of $8 \mathrm{t} / \mathrm{ha}, \mathrm{F}_{3}-\mathrm{SSNM}$ for the target yield of $9 \mathrm{t} / \mathrm{ha}, \mathrm{F}_{4}-\mathrm{SSNM}$ for the target yield of 10 $\mathrm{t} /$ ha and $\mathrm{F}_{5^{-}}$Recommended Dose of 
Fertilizer). The soil type of the experimental site was medium black soil having initial soil $\mathrm{pH}, \mathrm{EC}, \mathrm{N}, \mathrm{P}_{2} \mathrm{O}_{5}$ and $\mathrm{K}_{2} \mathrm{O}$ content was 8.24, $0.28 \mathrm{Ds} / \mathrm{m}, 173.50 \mathrm{~kg} / \mathrm{ha}, 85.50 \mathrm{~kg} / \mathrm{ha}$ and $442.70 \mathrm{~kg} / \mathrm{ha}$, respectively. The maize hybrid GK-5029 from Ganga Cauvery Seed Company was used and sown manually by dibbling seeds with spacing of $60 \mathrm{~cm} \times 20$ $\mathrm{cm}$. The crop was fertilized based on calculation made using" Nutrient Expert (NE) and computer based tool to recommend fertilizer. At the time of sowing, $25 \%$ of recommended nitrogen and $100 \%$ phosphorous and potassium were applied. The remaining nitrogen was top dressed at 20,35, 50 and 60 DAS. Weeds were managed with pre-emergence weedicide of atrazine 50\% WP (a) $1.0 \mathrm{~kg}$ a.i/ha. Irrigations and plant protection measures were taken as per the state recommendations.

\section{Results and Discussion}

\section{Yield and yield parameters}

Pooled over two years (2012 and 2013) data indicated that main plots viz., zero till with mulch and zero till without mulch did not differed significantly with respect to all growth parameters, yield parameters and yield. Whereas, SSNM practice for different target yield was found significant.

Grain and stover yield was significantly higher with SSNM for the target yield of 10 t/ha (9405 and $9846 \mathrm{~kg} / \mathrm{ha})$ which was on par with SSNM for the target yield of $9 \mathrm{t} / \mathrm{ha}$ (8543 and $8900 \mathrm{~kg} / \mathrm{ha}$ ) (Table 1). Yield improvement with NE-based fertilizer recommendation could primarily be attributed to a balanced application of nutrients than increasing the nutrient rates. This clearly explains how NE helped in promoting balanced use of all the essential nutrients thereby improving yields and optimizing nutrient use in the maize crop. The NE program recommended application of secondary and micronutrients especially $\mathrm{Zn}$, $\mathrm{Mg}$, and $\mathrm{Fe}$ whereas, NE-based recommendations bridged such gaps and provided optimum rates of $\mathrm{K}$ recommendations in the respective fertilizer schedules. The above results are in line with the findings of Satyanaraya et al., (2012) in field evaluation of NE maize was conducted in varying maize growing environments, under rainfed and assured irrigated conditions, at 82 major maize growing sites in southern India.

Similarly, the increase in grain yield and stover yield could also be attributed to increase in number of rows per cob and number of grains per cob when compared to state recommendations. With respect to yield parameters also zero tillage with mulch and without mulch did not found significant whereas, SSNM practices for the target yield of 10 t/ha was significantly higher with respect to number of rows per cob and number of grains per cob (15.02 and 616 respectively) which was on par with SSNM for the target yield of $9 \mathrm{t} / \mathrm{ha}$ (14.42 and 571, respectively).

Significantly lower grain yield, number of cobs and number of grains per cob was recorded with recommended dose of fertilizer (SRDF). This could be attributed to increase in growth parameters viz., plant height and number leaves per plant. With respect to growth parameters also zero tillage with and without mulch found non-significant (Table 2).

\section{Growth parameters}

Nevertheless, significant variation was observed with varied nutrient levels as per the NE practice. Significantly higher plant height and number leaves per plant was recorded with SSNM for the target yield of $10 \mathrm{t} / \mathrm{ha}$ 
(267.42 $\mathrm{cm}$ and $17.67 \mathrm{~cm}$, respectively). Significantly lower plant height and number of leaves per plant was recorded with state recommendation fertilizer, which could be due to imbalance fertilizer for rice fallow system leads to less efficiency of different nutrients (Table 3). Application of existing fertilization practices, developed decades ago, may not match uptake requirements of modern hybrids that are now grown at population densities higher than ever before. Nutrient requirement of maize varies from field to field due to high variability in soil fertility across farmer fields, and single homogenous nutrient recommendations may not be very useful in improving maize yields (Jat et al., 2013).

Table.1 Effect of site specific nutrient management on grain and stover yield of

Maize under zero tillage in TBP command area

\begin{tabular}{|c|c|c|c|c|c|c|}
\hline Treatments & \multicolumn{3}{|c|}{ Grain yield (kg/ha) } & \multicolumn{3}{|c|}{ Stover yield (kg/ha) } \\
\hline Main plots (M) & 2012 & 2013 & Pooled & 2012 & 2013 & Pooled \\
\hline $\mathrm{M}_{1}$ - Zero tillage with mulch & 7771 & 7485 & 7628 & 8268 & 8225 & 8247 \\
\hline $\begin{array}{l}\mathrm{M}_{2^{-}} \text {Zero tillage without } \\
\text { mulch }\end{array}$ & 7799 & 7742 & 7770 & 8178 & 8291 & 8280 \\
\hline S.Em \pm & 113 & 173 & 132 & 230 & 422 & 318 \\
\hline C.D. @ 5\% & NS & NS & NS & NS & NS & NS \\
\hline Sub plots $(\mathrm{F})$ & & & & & & \\
\hline $\begin{array}{l}\mathrm{F}_{1}-\mathrm{SSNM} \text { for the target yield } \\
\text { of } 7 \mathrm{tha}^{-1}\end{array}$ & 7842 & 7230 & 7536 & 8223 & 8169 & 8196 \\
\hline $\begin{array}{l}\mathrm{F}_{2^{-}} \text {SSNM for the target yield } \\
\text { of } 8 \mathrm{tha}^{-1}\end{array}$ & 8160 & 7966 & 8063 & 8625 & 8271 & 8448 \\
\hline $\begin{array}{l}\mathrm{F}_{3}-\mathrm{SSNM} \text { for the target yield } \\
\text { of } 9 \mathrm{tha}^{-1}\end{array}$ & 8522 & 8565 & 8543 & 8879 & 8920 & 8900 \\
\hline $\begin{array}{l}\mathrm{F}_{4}-\mathrm{SSNM} \text { for the target yield } \\
\text { of } 10 \mathrm{tha}^{-1}\end{array}$ & 9520 & 9290 & 9405 & 9985 & 9707 & 9846 \\
\hline $\mathrm{F}_{5}-\mathrm{SRDF}(150: 75: 37.5)$ & 4882 & 5016 & 4949 & 5402 & 6050 & 5726 \\
\hline S.Em \pm & 474 & 396 & 303 & 357 & 565 & 342 \\
\hline C.D. @ 5\% & 1305 & 1140 & 942 & 923 & 1598 & 926 \\
\hline Interactions (M X F) & NS & NS & NS & NS & NS & NS \\
\hline
\end{tabular}


Table.2 Effect of site specific nutrient management on no. of rows per cob and no. of grains per cob of maize under zero tillage in TBP command area

\begin{tabular}{|c|c|c|c|c|c|c|}
\hline Treatments & & f rows & & & grains & cob \\
\hline Main plots (M) & 2012 & 2013 & Pooled & 2012 & 2013 & Pooled \\
\hline $\mathrm{M}_{1}$ - Zero tillage with mulch & 13.80 & 13.87 & 13.97 & 536 & 546 & 552 \\
\hline $\begin{array}{l}\mathrm{M}_{2^{-}} \text {Zero tillage without } \\
\text { mulch }\end{array}$ & 13.87 & 14.10 & 13.98 & 558 & 574 & 569 \\
\hline S.Em \pm & 0.47 & 0.09 & 0.51 & 35 & 23 & 23 \\
\hline C.D. @ 5\% & NS & NS & NS & NS & NS & NS \\
\hline Sub plots $(\mathrm{F})$ & & & & & & \\
\hline $\begin{array}{l}F_{1}-\text { SSNM for the target } \\
\text { yield of } 7 \mathrm{t} \mathrm{ha}^{-1}\end{array}$ & 13.67 & 14.00 & 13.96 & 507 & 525 & 515 \\
\hline $\begin{array}{l}\mathrm{F}_{2-} \text { SSNM for the target } \\
\text { yield of } 8 \mathrm{tha}^{-1}\end{array}$ & 14.17 & 14.50 & 14.25 & 547 & 544 & 538 \\
\hline $\begin{array}{l}\mathrm{F}_{3^{-}} \text {SSNM for the target } \\
\text { yield of } 9 \mathrm{tha}^{-1}\end{array}$ & 14.17 & 14.33 & 14.42 & 564 & 558 & 571 \\
\hline $\begin{array}{l}\mathrm{F}_{4^{-}} \text {SSNM for the target } \\
\text { yield of } 10 \mathrm{tha}^{-1}\end{array}$ & 15.83 & 14.75 & 15.02 & 610 & 633 & 619 \\
\hline $\mathrm{F}_{5}-\mathrm{SRDF}(150: 75: 37.5)$ & 11.33 & 12.33 & 11.93 & 458 & 408 & 433 \\
\hline S.Em \pm & 0.59 & 0.53 & 0.53 & 34 & 38 & 27 \\
\hline C.D. @ 5\% & 1.45 & 1.32 & 1.63 & 81 & 110 & 67 \\
\hline Interactions (M X F) & NS & NS & NS & NS & NS & NS \\
\hline
\end{tabular}


Table.3 Effect of site specific nutrient management on plant height and number of leaves per Plant of maize under zero tillage in TBP command area

\begin{tabular}{|c|c|c|c|c|c|c|}
\hline \multirow{2}{*}{$\begin{array}{l}\text { Treatments } \\
\text { Main plots (M) }\end{array}$} & \multicolumn{3}{|c|}{ Plant height (cm) } & \multicolumn{3}{|c|}{ No. of leaves per plant } \\
\hline & 2012 & 2013 & Pooled & 2012 & 2013 & Pooled \\
\hline $\mathrm{M}_{1}$ - Zero tillage with mulch & 251.71 & 254.37 & 253.04 & 15.17 & 15.62 & 15.40 \\
\hline $\begin{array}{l}\mathrm{M}_{2^{-}} \text {Zero tillage without } \\
\text { mulch }\end{array}$ & 246.53 & 250.73 & 248.63 & 14.93 & 15.40 & 15.17 \\
\hline S.Em \pm & 5.51 & 4.70 & 5.06 & 0.34 & 0.47 & 0.40 \\
\hline C.D. @ 5\% & NS & NS & NS & NS & NS & NS \\
\hline \multicolumn{7}{|l|}{ Sub plots $(\mathrm{F})$} \\
\hline $\begin{array}{l}F_{1}-\text { SSNM for the target } \\
\text { yield of } 7 \mathrm{t} \mathrm{ha}^{-1}\end{array}$ & 245.70 & 250.70 & 248.20 & 14.37 & 14.82 & 14.59 \\
\hline $\begin{array}{l}\mathrm{F}_{2}-\mathrm{SSNM} \text { for the target } \\
\text { yield of } 8 \mathrm{tha}^{-1}\end{array}$ & 248.00 & 252.33 & 250.17 & 15.27 & 15.47 & 15.37 \\
\hline $\begin{array}{l}\mathrm{F}_{3^{-}} \text {SSNM for the target } \\
\text { yield of } 9 \mathrm{tha}^{-1}\end{array}$ & 254.23 & 259.90 & 257.07 & 16.00 & 16.63 & 16.32 \\
\hline $\begin{array}{l}\mathrm{F}_{4^{-}} \text {SSNM for the target } \\
\text { yield of } 10 \mathrm{tha}^{-1}\end{array}$ & 265.83 & 269.00 & 267.42 & 17.50 & 17.83 & 17.67 \\
\hline $\mathrm{F}_{5}-\mathrm{SRDF}(150: 75: 37.5)$ & 231.83 & 230.83 & 231.33 & 13.13 & 13.80 & 13.47 \\
\hline S.Em \pm & 8.43 & 5.78 & 6.76 & 0.63 & 0.50 & 0.49 \\
\hline C.D. @ 5\% & 23.87 & 16.26 & 17.33 & 1.84 & 1.57 & 1.45 \\
\hline Interactions (M X F) & NS & NS & NS & NS & NS & NS \\
\hline
\end{tabular}


Table.4 Effect of site specific nutrient management on net returns and B: C ratio of maize under Zero tillage in TBP command area

\begin{tabular}{|c|c|c|c|c|c|c|}
\hline \multirow{2}{*}{$\begin{array}{l}\text { Treatments } \\
\text { Main plots }(\mathrm{M})\end{array}$} & \multicolumn{3}{|c|}{ Net returns (Rs./ha) } & \multicolumn{3}{|c|}{ B:C ratio } \\
\hline & 2012 & 2013 & Pooled & 2012 & 2013 & Pooled \\
\hline $\mathrm{M}_{1}$ - Zero tillage with mulch & 80426 & 75145 & 78452 & 3.19 & 3.00 & 3.15 \\
\hline $\begin{array}{l}\mathrm{M}_{2^{-}} \text {Zero tillage without } \\
\text { mulch }\end{array}$ & 81854 & 79652 & 81200 & 3.29 & 3.15 & 3.26 \\
\hline S.Em \pm & 1700 & 2601 & 2020 & 0.05 & 0.07 & 0.06 \\
\hline C.D. @ 5\% & NS & NS & NS & NS & NS & NS \\
\hline \multicolumn{7}{|l|}{ Sub plots $(\mathrm{F})$} \\
\hline $\begin{array}{l}\mathrm{F}_{1-} \mathrm{SSNM} \text { for the target } \\
\text { yield of } 7 \mathrm{t} \mathrm{ha}^{-1}\end{array}$ & 81546 & 71220 & 76933 & 3.26 & 2.91 & 3.13 \\
\hline $\begin{array}{l}\mathrm{F}_{2^{-}} \mathrm{SSNM} \text { for the target } \\
\text { yield of } 8 \mathrm{tha}^{-1}\end{array}$ & 85664 & 81515 & 84173 & 3.33 & 3.15 & 3.29 \\
\hline $\begin{array}{l}\mathrm{F}_{3^{-}} \mathrm{SSNM} \text { for the target } \\
\text { yield of } 9 \mathrm{t} \mathrm{ha}^{-1}\end{array}$ & 89774 & 89281 & 90077 & 3.36 & 3.28 & 3.37 \\
\hline $\begin{array}{l}\mathrm{F}_{4^{-}} \mathrm{SSNM} \text { for the target } \\
\text { yield of } 10 \mathrm{t} \mathrm{ha}^{-1}\end{array}$ & 103545 & 98995 & 101803 & 3.64 & 3.45 & 3.59 \\
\hline $\mathrm{F}_{5}-\mathrm{SRDF}(150: 75: 37.5)$ & 45170 & 45983 & 46143 & 2.61 & 2.57 & 2.65 \\
\hline S.Em \pm & 7116 & 5945 & 4670 & 0.19 & 0.16 & 0.13 \\
\hline C.D. @ 5\% & 22086 & 16604 & 12899 & 0.60 & 0.34 & 0.39 \\
\hline Interactions (M X F) & NS & NS & NS & NS & NS & NS \\
\hline
\end{tabular}

The quantity of fertilizer was applied to different target yield treatments under Zero tillage as per NE

\begin{tabular}{|l|l|l|l|c|c|}
\hline \multicolumn{1}{|c|}{ Target yield } & \multicolumn{1}{|c|}{$\mathbf{N}$} & \multicolumn{1}{|c|}{$\mathbf{P}_{\mathbf{2}} \mathbf{O}_{\mathbf{5}}$} & \multicolumn{1}{|c|}{$\mathbf{K}_{\mathbf{2}} \mathbf{O}$} & $\mathbf{Z n S o}_{4}$ & $\mathbf{M g ~ S o}_{4}$ \\
\hline $\mathbf{7 . 0}$ t/ha & 150 & 41 & 38 & 25 & 25 \\
\hline $\mathbf{8 . 0}$ t/ha & 180 & 46 & 60 & 25 & 25 \\
\hline $\mathbf{9 . 0}$ t/ha & 191 & 57 & 70 & 25 & 25 \\
\hline $\mathbf{1 0 . 0}$ t/ha & 230 & 64 & 81 & 25 & 25 \\
\hline RDF & 150 & 75 & 37.5 & 25 & 25 \\
\hline
\end{tabular}


Economics feasibility of maize in rice fallows in TBP command area

There was no much difference between zero tillage with mulch and without mulch treatments with respect to cost of production (Table 4). The cost of production maize under zero tillage with much comes to Rs. 35,967 per ha when compared to without mulch treatment (Rs. 35,357 per ha). Among nutrient levels, SSNM for the target yield of $10 \mathrm{t} / \mathrm{ha}$ recorded highest cost of production (Rs. 39,267 per ha) as compared to state recommended dose of fertilizer which was recorded cost production of Rs. 28,028 per ha. With respect to gross returns, highest gross returns was recorded with fertilizer application based on nutrient expert for the target yield of $10 \mathrm{t} / \mathrm{ha}$ (Rs. 1,41,070 per ha as compared to state fertilizer recommendation (Rs. 74,232 per ha). With regard to net returns and benefit cost ratio, zero tillage with mulch and without mulch did not differ significantly. Although non-significant in both the years, during second year zero till without mulch treatment gave more yield than with mulch. As per my observation, this could be due to high stem borer incidence in zero till with mulch treatment leads to reduction in maize plant population as compare to lower incidence in without mulch treatment.

Nevertheless, NE practice for different target yield levels differed each other and significantly higher net returns and B: C ration was recorded with SSNM for the target yield of 10 t/ha (Rs. 1,01,803 per ha and 3.59, respectively) as compared to state recommendation of fertilizer (Rs. 46,143 per ha and 2.65 , respectively) which was recorded significantly lower net returns and benefit cost ratio (Table 4). Which could be due to more efficiency of fertilizer and balanced nutrition with both micro and macro nutrients and also high yield potential of maize hybrids may result in higher gross and net returns.
This could also be due to less phosphorous and potassium fertilizer in NE practice as compared to state recommendation leads to less cost of cultivation in TBP command area. The above results are in line with the findings of Biradar et al., (2012).

In conclusion, Nutrient Expert-based field specific fertilizer recommendations adopted and tested in TBP command areas of Karnataka results in increased yield and economic benefits through balanced application of nutrients. NE-based fertilizer recommendations generated on the principles of SSNM performed better than FP and SR for maize. Besides providing location specific nutrient recommendations rapidly, the tool has options to tailor recommendations based on resource availability to the farmers. There is a need to rapidly disseminate NE-based fertilizer recommendations for maize through extension agents and we anticipate that a user friendly tool like NE-Maize, with its robust estimation of site-specific nutrient recommendations, will be attractive to extension specialists working with small holder farmers in the in region.

\section{References}

Dass, S. Maize research in India-historical prospective and future. Maize Journal. 2012:1(1): 7-12.

ASG, 2011. Annual report. Directorate of Economics and Statistics, Govt. of India, New Delhi.

Pampolino, M. Better Crops with Plant Food. 2012: (Accepted, In Press)

Satyanarayana, T., Mujumdar. K., Pampolino M. and Johson. AM. Nutrient expert ${ }^{\mathrm{TM}}$ : A tool to optimize nutrient use and improve productivity of maize. Better crops-south Asia. 2012: 6 (1):4-8.

Jat, ML, Satyanarayana T. and Kaushik Majumdar. Fertilizer best management practice for maize system. Indian 
journal of fertilizer. 2013: 9 (4):80-94. Biradar DP, Aladakatti YR., Shivamurthy D, Satyanarayana $\mathrm{T}$ and Mujumdar $\mathrm{K}$. Managing fertilizer nitrogen to optimize yield and economics of maize - wheat cropping system in northern Karnataka. Better crops-south Asia. 2012: 6(1):1921.

\section{How to cite this article:}

Anand, S.R., J. Vishwanatha and Rajkumar, R.H. 2017. Site Specific Nutrient Management (SSNM) Using "Nutrient Expert" for Hybrid Maize (Zea mays L.) Under Zero Tillage in Thungabhadra Project (TBP) Command Area of Karnataka. Int.J.Curr.Microbiol.App.Sci. 6(8): 3597-3605. doi: https://doi.org/10.20546/ijcmas.2017.608.432 